\title{
„Filozofia Zrównoważonego Rozwoju” XXII Konferencja naukowa - 22 listopada 2018 r. (kilka refleksji uczestniczki)
}

Zrównoważony rozwój (ZR), czyli koncepcja rozwoju społeczno-gospodarczego uwzględniającego aspekty ekologiczne od lat 80 . XX wieku uznawana jest za paradygmat rozwoju tak globalnego, jak i lokalnego ${ }^{1}$. Jednym z głównych założeń ZR jest zasada sprawiedliwości wewnątrz- i międzygeneracyjnej, zakładająca, że sposób gospodarowania (korzystania z dóbr) uwzględnia potrzeby wszystkich ludzi współcześnie żyjących, równocześnie nie umniejszając możliwości (szans) zaspokajania potrzeb przyszłych pokoleń (często przywoływanym mottem koncepcji ZR jest stwierdzenie, że Ziemi nie otrzymaliśmy od naszych ojców, pożyczyliśmy ją od naszych wnuków).

Ponad 30 lat realizacji koncepcji ZR pozwala zauważyć ewolucje, zmiany głównych celów i wątków tematycznych wynikających z globalnych zagrożeń, ale i rozwoju nauki i techniki. Pierwotnie (szczególnie w Polsce) podkreślany był środowiskowy, ekologiczny aspekt ZR. Lata 90. XX wieku, szczególnie po Szczycie Ziemi w Rio do Janeiro, to rozkwit podejścia zintegrowanego obejmującego wszystkie aspekty ZR: tj. ekonomiczny, społeczny, ekologiczny i instytucjonalny, zaś przełom wieków wiąże się z rozwojem koncepcji społecznej odpowiedzialności organizacji, ekonomii współdzielenia oraz ekonomi cyrkularnej.

Przełomem dla współczesnego podejścia do koncepcji ZR było przyjęcie w 2015 r. nowych Celów Zrównoważonego Rozwoju ONZ (Sustainable Development Goals - SDGs). Owe 17 celów² wyraźnie wskazuje, że pełne wdrożenie koncepcji ZR, wymaga współpracy wielu grup interesariuszy. Szczególne znaczenie w tym procesie powinny spełniać uczelnie wyższe, jako miejsca edukacji na rzecz ZR, ale także kształtowania postaw i praktycznego implementowania wymogów zawartych w poszczególnych SDGs. Wychodząc z tej przesłanki kluczowe wydaje się prowadzenie badań naukowych w zakresie ZR, ale także organizowanie konferencji i debat.

Od ponad 20 lat interdyscyplinarne dyskusje naukowe wokół problematyki ZR toczą się na Uniwersytecie Kardynała Stefana Wyszyńskiego w Warszawie. Rokrocznie w tej uczelni organizowana jest konferencja pod hasłem „Filozofia Zrównoważonego Rozwoju” - w 2018 roku odbyła się już XXII konferencja z tego cyklu.

Dyskusje w ramach konferencji mają zawsze tło filozoficzne (aspekty filozofii zrównoważonego rozwoju czy etyki środowiskowej). W czasie XXII konferencji sesja plenarna (wprowadzająca) zgromadziła uznane autorytety w dziedzinie ZR. Mówcami w tej sesji byli:

\footnotetext{
1 Najczęściej za początek szerokiego uwzględniania koncepcji ZR w polityce rozwoju uznaje się 1987 rok i opublikowanie Raportu Światowej Komisji ds. Środowiska i Rozwoju (zwanej też „Komisją Brundtland” od nazwiska jej przewodniczącej Gro Harlem Brundtland) pt. „Nasza wspólna przyszłość”. Kontynuacją ustaleń raportu był I Szczyt Ziemi, który odbył się w 1992 r. w Rio de Janeiro i doprowadził do przyjęcia Globalnej Agendy 21.

2 Pełną prezentację celów rozwoju zrównoważonego (w tym przewidzianych w ich ramach działań) można odnaleźć na oficjalnej stronie: http://www.un.org.pl/
} 
prof. Zbigniew Hull (Filozofia zrównoważonego rozwoju w realizacji tej idei w praktyce), prof. Włodzimierz Tyburski (Zrównoważony rozwój - oczekiwania i stan), prof. Andrzej Papuziński (Zło ekologiczne. Czy istniej zło ekologiczne?) i prof. Helena Ciążela (Kryzys neoliberalizmu a rozwój zrównoważony). Nakreślenie teoretycznych ram i wskazanie na jakim etapie wdrażania rozwoju zrównoważonego jesteśmy (dość krytyczne i momentami pesymistyczne) pozwoliło na kontynuowanie dyskusji konferencyjnej w sekcjach tematycznych, których było aż sześć (w nawiasach podano liczbę wystąpień w ramach poszczególnych sekcji):

- Rozwój zrównoważony w perspektywie filozoficznej (6)

- Edukacja na rzecz zrównoważonego rozwoju (6)

- Rozwój zrównoważony w ujęciu nauk przyrodniczych (6)

- Społeczno-ekonomiczne aspekty zrównoważonego rozwoju (4)

- Praktyczne aspekty zrównoważonego rozwoju (5)

- Wielowymiarowość zrównoważonego rozwoju (4).

Łącznie w czasie konferencji zaprezentowano 35 wystąpień (sesja plenarna i sesje tematyczne). Ze względu na ograniczenia czasowe (konferencja jest jednodniowa) niektóre sesje tematyczne odbywały się równolegle, co zawsze dla uczestników jest pewnym dylematem - co wybrać? Organizatorzy zapewnili jednak możliwość choćby informacyjnego zapoznania się z referatami przedstawianymi podczas sesji tematycznych - na zakończenie konferencji odbyła się bowiem sesja podsumowująca, w czasie której prowadzący poszczególne sesje tematyczne przedstawiali główne myśli/refleksje/wnioski referentów.

Wydźwięk sesji tematycznych był bardziej optymistyczny niż sesji planarnej i pozwolił wskazać warunki i szanse pełnego wdrożenia ZR. W sesjach tematycznych często bowiem prezentowano badania szczegółowe oraz lokalne, oddolne inicjatywy i działania podejmowane na rzecz ZR, a tych dzieje się w różnych obszarach (tematycznych i terytorialnych) bardzo wiele, tak w Polsce, jak i na świecie.

W czasie podsumowania najdobitniej widać było mocną stronę tej konferencji, tj. jej wielowymiarowość i wielowątkowość. Tak jak koncepcja ZR jest wielowymiarowa i nie może być rozpatrywana tylko na gruncie jakieś jednej wybranej dziedziny nauki, tak dyskusja w bardzo zróżnicowanym naukowym gronie (filozofów, ekonomistów, przyrodników), łącząca wątki naukowe i praktyczne, pozwala na poszukiwanie nowych obszarów badawczych (w tym zintegrowania i holistycznego podejścia do implementacji ZR).

Jest to też doskonała okazja do swoistego "przeglądu” kierunków badań, które prowadzone są w ośrodkach naukowych zajmujących się różnymi aspektami ZR. Jak co roku, organizatorzy zapewnili, że za rok kolejna edycja konferencji, a w międzyczasie ukaże się publikacja podsumowująca dyskusje w ramach XXII konferencji. 